\title{
High-velocity impact behavior of hybrid fiber-reinforced epoxy composites
}

\author{
Clifton Stephen $^{1} \cdot$ B. Shivamurthy ${ }^{2}\left(\mathbb{D} \cdot\right.$ Abdel-Hamid I. Mourad $^{3} \cdot$ Rajiv Selvam $^{1}$
}

Received: 27 May 2021 / Accepted: 2 August 2021 / Published online: 22 August 2021

(c) The Author(s) 2021

\begin{abstract}
In this study, non-hybrid and hybrid (Kevlar, carbon and glass) fabric epoxy composite laminates were fabricated with different stacking sequences by hand lay-up followed by hot-compression molding. Experimental tests were conducted to investigate tensile, flexural, and hardness characteristics. It was found that the stacking sequence did not significantly affect the tensile strength and hardness values of the composites; however, it affected their flexural strength. Damage morphology of the specimens through SEM images showed that the major damage mechanisms in the composites were delamination, fiber breakage, pull-out, and matrix cracking. Based on the static experimental results, the high-velocity impact behavior was investigated through simulation study using LS-DYNA finite element analysis (FEA) software. To study the ballistic impact, a steel projectile with a hemispherical penetrating edge at impact velocities of $100 \mathrm{~m} . \mathrm{s}^{-1}, 250 \mathrm{~m} \cdot \mathrm{s}^{-1}$, and $350 \mathrm{~m} \cdot \mathrm{s}^{-1}$ was considered. Among non-hybrid fabric epoxy composite specimens, Kevlar/epoxy specimen was found to have the highest impact energy absorption followed by carbon/epoxy and glass/epoxy, respectively. Regarding the hybrid fabric epoxy composite specimens, the ones with Kevlar plies in the rear face exhibited better energy absorption compared to other stacking sequences. The non-hybrid glass/epoxy specimen had the lowest energy absorption and highest post-impact residual velocity of projectile among all specimens. From the FEA results, it was noted that impact resistance of hybrid composites improved when Kevlar fabric was placed in the rear layer. Thus, the stacking sequence was observed to be of substantial importance in the development of fabric-reinforced composite laminates for high-velocity impact applications.
\end{abstract}

Keywords Hybrid fabric-reinforced epoxy composites $\cdot$ Mechanical properties $\cdot$ Finite element simulation $\cdot$ High-velocity impacts $\cdot$ Damage mechanisms

Technical Editor: Monica Carvalho.

B. Shivamurthy

shiva.b@manipal.edu

Clifton Stephen

clifton211192@yahoo.com

Abdel-Hamid I. Mourad

ahmourad@uaeu.ac.ae

Rajiv Selvam

rajiv.selvam@manipaldubai.com

1 Department of Mechanical Engineering, School of Engineering and Information Technology, Manipal Academy of Higher Education, Dubai, UAE

2 Department of Mechanical and Manufacturing Engineering, Manipal Institute of Technology, Manipal Academy of Higher Education, Manipal 576104, India

3 Department of Mechanical Engineering, United Arab Emirates University, Post Office Box 15551, Al Ain, UAE

\section{Introduction}

Components made of fabric/fiber-reinforced polymer (FRP) composites have been used in aerospace, defense, railways, automobile, and various other industrial sectors due to their attractive mechanical properties, high strength-to-weight ratio, non-corrosion, high durability, resilience, dimensional stability, and ease to manufacture [1]. These components may be subjected to impact loads during in-service or maintenance. Most of the damage developed in the components due to low-velocity impact is barely visible and further leads to catastrophic failure. Hence, the study on impact behavior and structure-property of FRP composites is an important research topic [2].

It is reported that FRP composites consisting of two or more types of fibers/fabrics or both fiber/fabric and fillers as reinforcement are called hybrid FRP composites. These have better fatigue and penetration resistance with higher 
strength and stiffness compared to non-hybrid FRP composites. However, the type of fiber, matrix, thickness of laminate, geometry, and boundary conditions in addition to stacking sequence of fabric, and fiber architecture affect their response against impact loads [3]. The impact response also depends upon the size, shape, and kinetic energy of the projectile. The impact resistance also depends on the structure-property of the FRP composites. Fabrication method also plays a crucial role in the development of defect-free components. The voids in hybrid FRP composites developed during the fabrication process considerably retard the inter-laminar shear strength and flexural strength of FRP composites [4, 5]. Zhang et al. [6] and Murugan et al. [7] studied the tensile and flexural behavior of glass and carbonbased hybrid and non-hybrid composites. They reported that the stacking sequence of hybrid composites affected flexural and compressive properties when reinforcement fabrics were moved from top to bottom layer and vice versa. This was due to the different tensile and compressive strengths offered by carbon and glass fabrics. They also reported that nonhybrid glass-epoxy composite showed the lowest and the non-hybrid carbon-epoxy composite showed the highest tensile strength, modulus, and compressive strength compared to the glass-carbon-epoxy hybrid composites. Valenca et al. [8] reported the Kevlar-49 fiber with $S$-glass fiber hybrid fabric epoxy matrix composites showed better mechanical properties compared to non-hybrid composites. Srivathsan et al. [9] reported that in Kevlar-glass-epoxy hybrid laminates, the alternative successive orientation of fabrics in the laminate showed better inter-laminar and flexural strength; the outermost fabric layers contribute its properties in transverse loading conditions. Thus, it is evident through literature, the hybridization in FRP composites is beneficial in terms of good performance for transverse loading and reduction of $25-30 \%$ in material cost.

Bulut and Erklig [10] fabricated non-hybrid and hybrid composites using Kevlar, carbon, and glass fabrics with epoxy matrix in various stacking sequences. They reported specimens, consisting of all three types of fabrics, stacked in G/K/C sequence recorded the highest impact energy absorption compared to other hybrid samples. Yanen et al. [11] also reported the impact response of hybrid fabric epoxy composite laminates consisting of Aramid, glass, and carbon in various fabric architecture such as plain woven, twill woven, and unidirectional fabric in four configurations. They observed that twill woven fabric exhibited enhanced penetration resistance compared to plain woven fabrics. For unidirectional fiber fabrics, the $45^{\circ}$ orientation had the highest impact resistance. Overall considering all specimens, laminates with $45^{\circ}$ orientation of fibers offered the highest ballistic limit velocity. Randjbaran et al. [12] fabricated hybrid fabric composite laminates by reinforcing Kevlar, carbon, and glass fabrics in the epoxy matrix in five stacking sequences such as (i) $\mathrm{K} / \mathrm{C} / \mathrm{G} / \mathrm{K} / \mathrm{G} / \mathrm{C}$, (ii) $\mathrm{G} / \mathrm{C} / \mathrm{K} / \mathrm{C} / \mathrm{K} / \mathrm{G}$, (iii) $\mathrm{K} / \mathrm{G} / \mathrm{C} / \mathrm{G} / \mathrm{C} / \mathrm{K}$, (iv) $\mathrm{G} / \mathrm{K} / \mathrm{C} / \mathrm{C} / \mathrm{G} / \mathrm{K}$, and (v) $\mathrm{K} / \mathrm{C} / \mathrm{G} / \mathrm{G} / \mathrm{C} / \mathrm{K}$. These laminates were subjected to high-velocity impact tests at $184 \mathrm{~m} . \mathrm{s}^{-1}$ impact velocity. They observed that specimen types (ii) and (iv) showed the best penetration resistance behavior compared to other specimens. Even though all specimens consisted of all the three reinforcement fabrics, the stacking sequence affected their impact behavior.

Further, the experimental investigation of the high-velocity impact behavior of FRP hybrid laminates involves high cost in terms of raw materials, labor, and testing. Therefore, FEA studies have been extensively used to understand the hybrid laminates' complex damage mechanisms and energy absorption behavior when subjected to high-velocity impact [13]. Sorrentino et al. [14] reported that the ballistic impact experimental results was $8 \%$ higher as compared to the analytical ballistic results of Kevlar-epoxy laminates. Bandaru et al. [15] investigated the high-velocity impact response of Kevlar-polypropylene hybrid composite through simulations using ANSYS AUTODYN software. They concluded that matrix cracking, shear plugging, and delamination were the major modes of failure. Shear plugging was the major energy-absorbing mechanism. Similarly, Kumar et al. [16] studied the effect of projectile mass and impact velocity on the ballistic performance of Kevlar-epoxy composite laminates. They have noticed that significant failure modes were delamination, fiber debonding, and matrix cracking. In most of all these studies, researchers recommended FEA can be considered as a reliable alternative to ballistic impact experimental tests [17].

Apart from impact resistance applications, hybrid FRP composites are also used for other applications such automotive and structural components and pipes. Ozbek et al. [18] fabricated hybrid and non-hybrid FRP pipes using glass and carbon filament-based intraply composites. Filament winding process was employed for the fabrication of pipe specimens. These pipes were subjected to lateral crushing loads, and their energy absorption behavior was studied. Delamination failure was the main damage mode observed in all specimens. Hybridization with glass fibers enhanced the energy absorption and crushing resistance of carbon composites. Also, neat glass/epoxy composite had the highest specific crushing strength compared to other tested composite configurations.

Through available literature $[1,19]$ it can thus be noted that Kevlar, carbon, and glass fabrics are ideal reinforcing materials commonly used for the fabrication of ballistic, automotive, and structural composites. As these applications involve occurrence of dynamic impact events during the service life of these composites, it is important to study their mechanical as well as high-velocity impact behavior. Even though literature is available on the study of stacking effect on the performance of hybrid 
composites consisting of two types of fabric as reinforcement, limited work has been reported on hybrid composites consisting of three types of fabric as reinforcement (Kevlar, carbon, and glass). Hence, in this work, an attempt was made to investigate the effect of various stacking sequences of glass, carbon, and Kevlar fabric layers in the hybrid composite laminates. It is necessary to compare the mechanical and impact behavior of twofabric and three-fabric hybrid composites. Similarly, the high-velocity impact behavior of two- and three-fabric hybrid composites at different impact velocities has not been widely reported. Thus, in the present work, effort was also made to study the effect of impact velocity on the residual velocity of FRP composites consisting of two- and three-fabric hybrid composites. The static mechanical properties are investigated through experimental tests as per ASTM standards. Further, the LSDYNA software platform has been used to study the highvelocity impact behavior of non-hybrid fabric epoxy and hybrid fabric epoxy composite laminates with various stacking sequences. This FE study is conducted as a precursor to experimental ballistic tests, which are costly and labor-intensive. The stacking sequence optimized through simulation tests will be chosen for experimental ballistic studies that will be performed in the future works. Also, hybridizing Kevlar (19.36 US\$ per $\mathrm{m}^{2}$ ) and carbon fabrics (18.36 US\$ per $\left.\mathrm{m}^{2}\right)$ with cheaper glass fabrics (3.52 US\$ per $\mathrm{m}^{2}$ ) without drastic reduction in mechanical and ballistic performance lead to reduced material cost in the development of FRP composites considered in this work. The development of such low-cost composites is bestsuited for impact resistance application such as bullet proofing and armor materials for law-enforcement agencies for which product cost is an important parameter.

\section{Materials and methods}

\subsection{Materials}

The hybrid FRP composite laminates were fabricated by using Kevlar-129 fabric (195 gsm), EC9-Glass fabric (201 gsm), and 3K-Carbon fabric (200 gsm) of bi-directional type as reinforcements. All these fabrics were procured from M/s. Fibermax Composites, Greece. Araldite LY564 epoxy resin and Aradur 2955 hardener received from Huntsman Chemicals, Switzerland, were used as the matrix formulation. The matrix (epoxy + hardener) had a density of $1.150 \mathrm{~g} . \mathrm{m}^{-3}$ and viscosity of $1.3 \mathrm{GPa}-\mathrm{s}$ at $25^{\circ} \mathrm{C}$. The casted matrix specimen had tensile and flexural strengths of $80 \mathrm{MPa}$ and $122 \mathrm{MPa}$, respectively, as per supplier data.

\subsection{Fabrication of laminates}

The non-hybrid laminates such as $\mathrm{C} / \mathrm{C} / \mathrm{C}, \mathrm{K} / \mathrm{K} / \mathrm{K}, \mathrm{G} / \mathrm{G} / \mathrm{G}$, and hybrid composite laminates with various stacking sequences $\mathrm{K} / \mathrm{G} / \mathrm{K}, \mathrm{K} / \mathrm{C} / \mathrm{K}, \mathrm{G} / \mathrm{C} / \mathrm{K}, \mathrm{C} / \mathrm{G} / \mathrm{K}$, and $\mathrm{K} / \mathrm{C} / \mathrm{G}$ were fabricated by hand lay-up followed by a hot-compression molding technique, where $\mathrm{C}, \mathrm{G}$, and $\mathrm{K}$ stand for carbon fabric, glass fabric, and Kevlar fabric, respectively. The curing conditions of $100{ }^{\circ} \mathrm{C}$ with $13.85 \mathrm{MPa}$ pressure were maintained for a period of $30 \mathrm{~min}$ in compression molding. The number of plies and stacking sequence of non-hybrid and hybrid fabric epoxy composite laminates is shown in Fig. 1. The laminates have a thickness of $3.1^{ \pm 0.15} \mathrm{~mm}$, and each laminate consists of 15 plies of reinforced fabric. Each laminate is made up of three layers; each layer consists of five plies of the same type of reinforcement fabric.

\subsection{Experimental tests}

The burn-off test as per ASTM D3171-15 [20] was followed to determine the vol.\% of fiber and voids in the composite laminates. The tensile behavior of non-hybrid and hybrid composites was investigated through tensile tests according to ASTM D638 [21]. A computerized universal testing machine (Tinius Olsen-50ST) and type-5 specimen have been used. For each type of laminate, five specimens were tested, and mean values of tensile strength and tensile modulus have been considered. The tensile modulus was measured using a video extensometer attached to the universal testing machine. A three-point bending test was performed to study the flexural behavior of all the composites according to ASTM D790 [22]. The flexural test was stopped when the deformation at the midspan of the specimen reached $25 \mathrm{~mm}$. The fractured specimen morphology is investigated using scanning electron microscope (JEOL—JCM 7000). The laminate hardness was estimated by the Rockwell-B hardness tester (Q1Test-SHR150M). The ballistic impact behavior is investigated by high-velocity impact (HVI) simulation on the non-hybrid and hybrid composites using LSDYNA finite element software.

\section{Results and discussion}

\subsection{Fiber and voids content}

Specimen of dimensions $10 \times 10 \times 3 \mathrm{~mm}^{3}$ was prepared from each laminate and weighed up to three decimal accuracy $\left(\mathrm{M}_{\mathrm{j}}\right)$. The specimen was kept in a crucible ( $\operatorname{mass} \mathrm{M}_{\mathrm{c}}$ ) and then placed into a preheated furnace at $440{ }^{\circ} \mathrm{C}$ for a duration of $30 \mathrm{~min}$. Further, the burnt specimen with the crucible was then placed in a desiccator and allowed to cool down to room temperature. The burnt specimen was washed to remove any 
Fig. 1 Stacking sequence of hybrid composite laminates
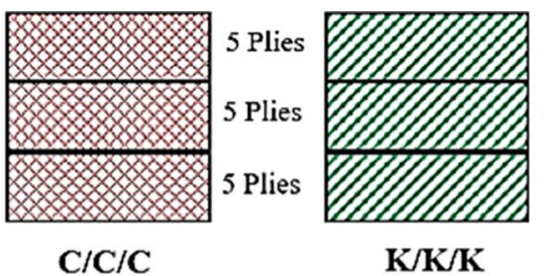
5 Plies
5 Plies
5 Plies

$\mathbf{K} / \mathbf{K} / \mathbf{K}$

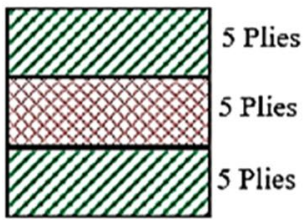

$\mathrm{K} / \mathrm{C} / \mathrm{K}$

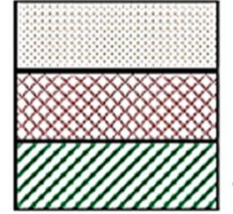

$\mathbf{G} / \mathbf{C} / \mathbf{K}$

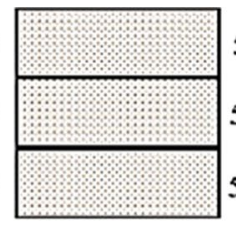

G/G/G

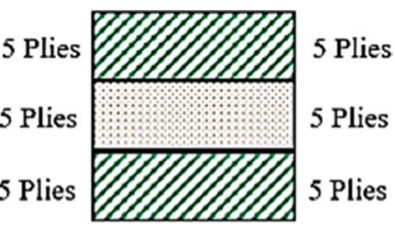

K/G/K
C

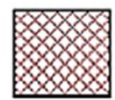

$\mathbf{K}$

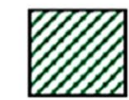

G

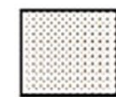

\section{Carbon/Epoxy Kevlar/Epoxy Glass/Epoxy}

matrix material in the form of ashes that were left behind after combustion. The final weight of the burnt specimen along with the crucible $\left(\mathrm{M}_{\mathrm{cr}}\right)$ was measured. The final weight of the combusted specimen containing only fiber $\left(\mathrm{M}_{\mathrm{f}}\right)$ is the difference between $\mathrm{M}_{\mathrm{cr}}$ and $\mathrm{M}_{\mathrm{c}}$. The volume percent of reinforcement fabric is calculated using Eq. (1).

$V_{f}=\left(\frac{M_{f}}{M_{i}}\right) \times 100 \mathrm{x}\left(\frac{\rho_{c}}{\rho_{f}}\right)$

where $\rho_{f}$ and $\rho_{c}$ are the density of the reinforcement fabric and actual density of the composite specimen $\left(\mathrm{g} . \mathrm{cm}^{-3}\right)$, respectively. The $\rho_{c}$ is calculated using Eq. (2).

$\rho_{c}=\frac{M_{i}}{V_{c}}$

where $V_{c}$ is the volume of the composite specimen.
The volume percent of the matrix $\left(V_{m}\right)$ is calculated using Eq. (3).

$V_{m}=\frac{\left(M_{i}-M_{f}\right)}{M_{i}} \times\left(\frac{\rho_{c}}{\rho_{m}}\right) \times 100$

where $\rho_{m}$ is the density of the matrix $\left(\mathrm{g} . \mathrm{cm}^{-3}\right)$. The volume percent of voids $\left(V_{v}\right)$ is calculated using Eq. (4).

$V_{v}=100-\left(V_{f}+V_{m}\right)$

For each laminate, five samples were tested and average reading was considered. The various non-hybrid and hybrid composites of fiber and voids volume percentage are presented in Table 1.

Voids are the most common manufacturing defects formed during the fabrication of FRP composites. Various researchers studied the effect of voids on the physical and
Table 1 Fiber and void content in non-hybrid and hybrid composites

\begin{tabular}{llllllll}
\hline $\begin{array}{l}\text { Composite } \\
\text { specimen }\end{array}$ & $\begin{array}{l}\rho_{c} \\
\left(\mathrm{~g} . \mathrm{cm}^{-3}\right)\end{array}$ & $\begin{array}{l}\rho_{f} \\
\left(\mathrm{~g} . \mathrm{cm}^{-3}\right)\end{array}$ & $\begin{array}{l}\rho_{m} \\
\left(\mathrm{~g} . \mathrm{cm}^{-3}\right)\end{array}$ & $\begin{array}{l}V_{f} \\
(\%)\end{array}$ & $\begin{array}{l}V_{m} \\
(\%)\end{array}$ & $\begin{array}{l}V_{v} \\
(\%)\end{array}$ & $\begin{array}{l}V_{f}(\%) \\
\text { as per literature }\end{array}$ \\
\hline $\mathrm{C} / \mathrm{C} / \mathrm{C}$ & 1.357 & 1.49 & 1.089 & 70.289 & 28.437 & 1.272 & $64.51[24], 70.00[25]$ \\
$\mathrm{K} / \mathrm{K} / \mathrm{K}$ & 1.052 & 1.06 & & 73.704 & 24.860 & 1.434 & $68.59[24], 68.20[26]$ \\
$\mathrm{G} / \mathrm{G} / \mathrm{G}$ & 1.641 & 1.94 & & 66.192 & 32.769 & 1.037 & $63.91[24], 73.14[27]$ \\
$\mathrm{G} / \mathrm{C} / \mathrm{K}$ & 1.318 & 1.496 & & 65.691 & 30.785 & 3.522 & $68.51[24]$ \\
$\mathrm{C} / \mathrm{G} / \mathrm{K}$ & 1.212 & 1.353 & & 67.243 & 27.734 & 5.021 & $65.43[24]$ \\
$\mathrm{K} / \mathrm{C} / \mathrm{K}$ & 1.148 & 1.203 & & 72.933 & 24.849 & 2.217 & $67.79[24]$ \\
$\mathrm{K} / \mathrm{G} / \mathrm{K}$ & 1.318 & 1.496 & & 69.711 & 24.683 & 5.605 & $67.84[24]$ \\
$\mathrm{K} / \mathrm{C} / \mathrm{G}$ & 1.308 & 1.496 & & 65.691 & 30.785 & 3.522 & $67.12[24]$ \\
\hline
\end{tabular}


thermomechanical properties of FRP composites [23]. In the present work, the tight weaving pattern of the fabrics, suitable resin viscosity (600 $\mathrm{mPa} . \mathrm{s})$, and optimized compression pressure (13.85 MPa) used in manufacturing composites led to low void content in the neat composites. The hybrid composites showed higher void content compared to non-hybrid composites attributed due to the difference in resin wettability of selected fabrics and compatibility of fabrics. However, the fiber volume content in the laminates is about $65-73 \%$, which is well within the range generally observed in the literature for similar FRP composites [24-27]. Also, the void content is below 5.6 Vol.\% for all fabricated samples as shown in Table 1. The high fiber volume content in the laminates is attributed to the selection of optimum fabrication process parameters and the materials used. Also, Gollins [28] reported that the fiber volume content of compression-molded FRP laminates is up to $20 \%$ higher compared to specimens of same thickness fabricated through other techniques.

\subsection{Tensile behavior}

The stress-strain curves of all the non-hybrid fabric/epoxy composite and hybrid fabric/epoxy composite samples are depicted in Fig. 2.

Figure 2 demonstrates that the non-hybrid carbon epoxy $(\mathrm{C} / \mathrm{C} / \mathrm{C})$ and non-hybrid glass epoxy $(\mathrm{G} / \mathrm{G} / \mathrm{G})$ composites show brittle behavior and more stiffness as compared to non-hybrid Kevlar epoxy $(\mathrm{K} / \mathrm{K} / \mathrm{K})$ composite. In hybrid specimens, the tensile curve showed a sudden drop in stress at a certain point and a further increase is seen. All hybrid composite specimens show this typical performance. This may be due to the sudden failure (delamination, crack propagation, etc.) of the weaker fabric layers, and the load was

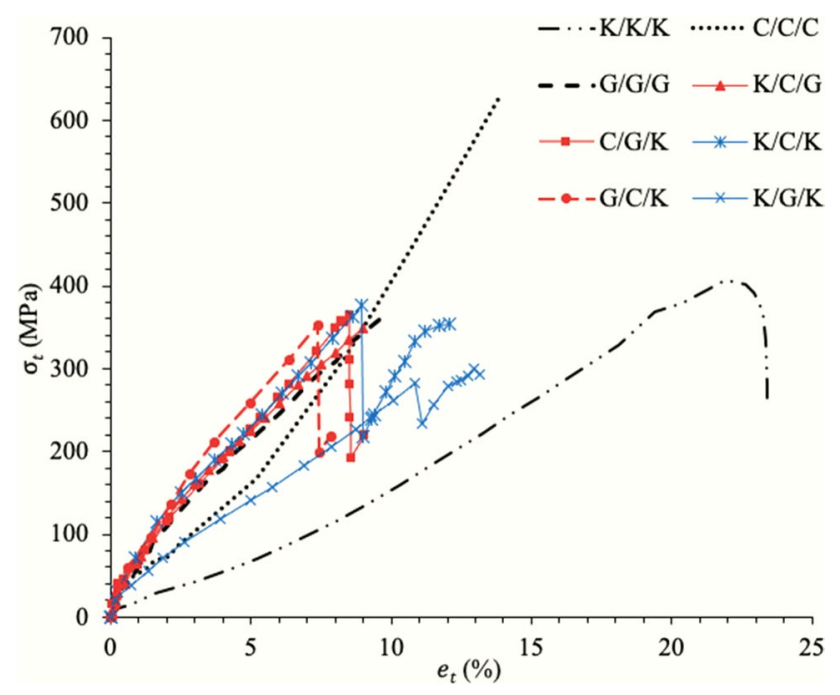

Fig. 2 Tensile stress-strain plot of non-hybrid and hybrid composites further carried by other fabric layers leading to an increase in the stress till the final separation of the specimen [29]. It is observed that the hybrid composites consisting of more Kevlar plies showed higher tensile strain as Kevlar fibers are more flexible compared to other fibers used in this study. Furthermore, the hybrid composites exhibited lower fracture strength if compared with non-hybrid composites. This could be due to the mismatch in the deformation, delamination between layers or voids/defects. In general, the failure or damage mechanism is complicated. This point requires more investigation and attention to improve the fracture strength of hybrid composites.

It can be noticed in Fig. 3 that $\mathrm{C} / \mathrm{C} / \mathrm{C}$ composite showed the highest $\sigma_{t}$ followed by $\mathrm{K} / \mathrm{K} / \mathrm{K}$ composite has the next highest. The $\sigma_{t}$ of $\mathrm{C} / \mathrm{C} / \mathrm{C}$ composite is in line with the results reported in the literature by Kadlec et al. [30]. However, the $\mathrm{K} / \mathrm{K} / \mathrm{K}$ composites showed slightly higher $\sigma_{t}$ as compared to results obtained by Rahul et al. [31]. This can be attributed to better mechanical properties of Kevlar-129 ballistic grade fabric used as reinforcement in this research. It can be noted that $\mathrm{G} / \mathrm{G} / \mathrm{G}$ composite laminates showed a lower tensile strength of $346 \mathrm{MPa}$ out of all the non-hybrid fabric composites. Considering hybrid fabric epoxy composite, the lowest $\sigma_{t}$ (of $289 \mathrm{MPa}$ ) was observed for $\mathrm{K} / \mathrm{G} / \mathrm{K}$ specimen. Delamination at the Kevlar-glass interface as shown in Fig. $4 \mathrm{e}$ is the cause of the lowest $\sigma_{t}$ in $\mathrm{K} / \mathrm{G} / \mathrm{K}$ specimen. Such delamination is due to the relative mismatch in the strain of glass (smallest strain) and Kevlar (largest strain) fabrics. The remaining hybrid fabric epoxy composite samples containing all three reinforcement fabrics had $\sigma_{t}$ in the range of 349-362 MPa. Thus, the sequence of fabric lay-up has no significant effect on $\sigma_{t}$. However, the slight variation in $\sigma_{t}$ observed is due to the volume fraction of the type of fibers in the composites. These different fiber volumes and fiber tensile strength are directly proportional and represent the $\sigma_{t}$ of that particular hybrid composite. In this work, all

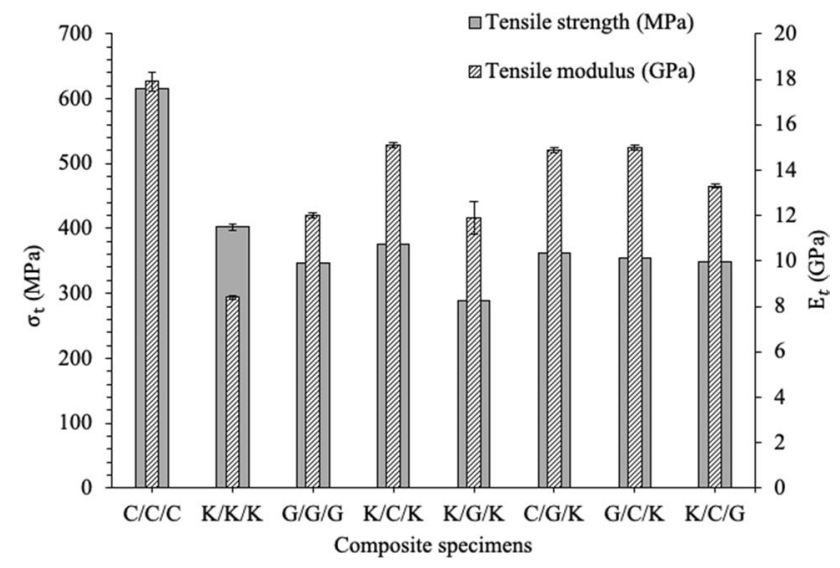

Fig. 3 The $\sigma_{t}$ and $E_{t}$ of non-hybrid and hybrid fabric epoxy composites 
Fig. 4 Photographs of nonhybrid and hybrid composite fractured tensile specimens

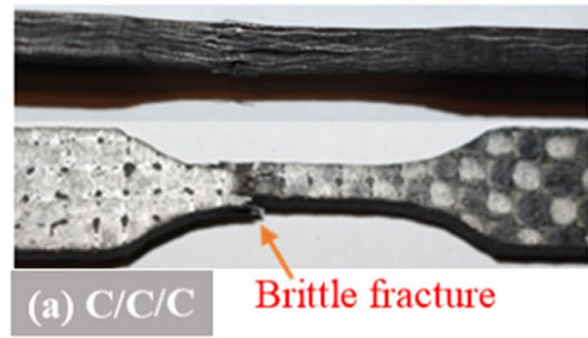

Fiber elongation and pull-out

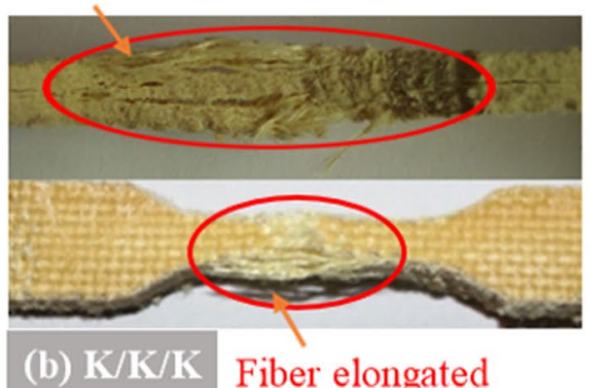

(b) $\mathrm{K} / \mathrm{K} / \mathrm{K}$ Fiber elongated
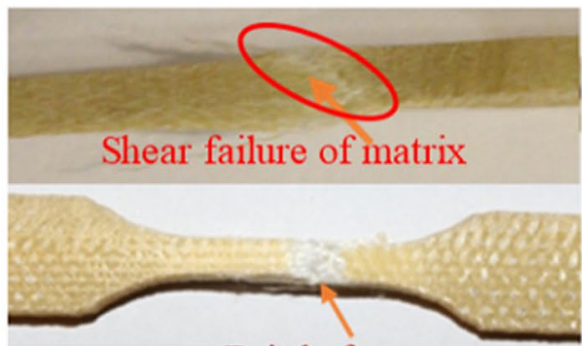

(c) $\mathrm{G} / \mathrm{G} / \mathrm{G}$

Fiber elongation, pull-out and fracture

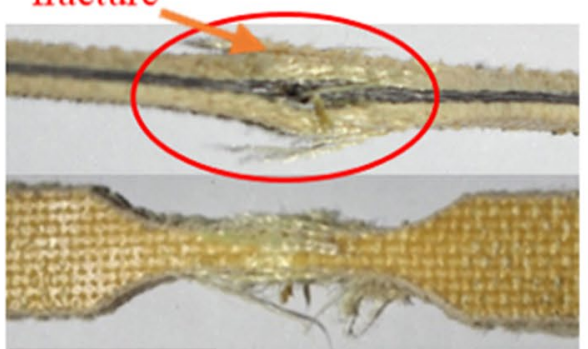

(d) $\mathrm{K} / \mathrm{C} / \mathrm{K}$
Fiber elongation, pull-out and
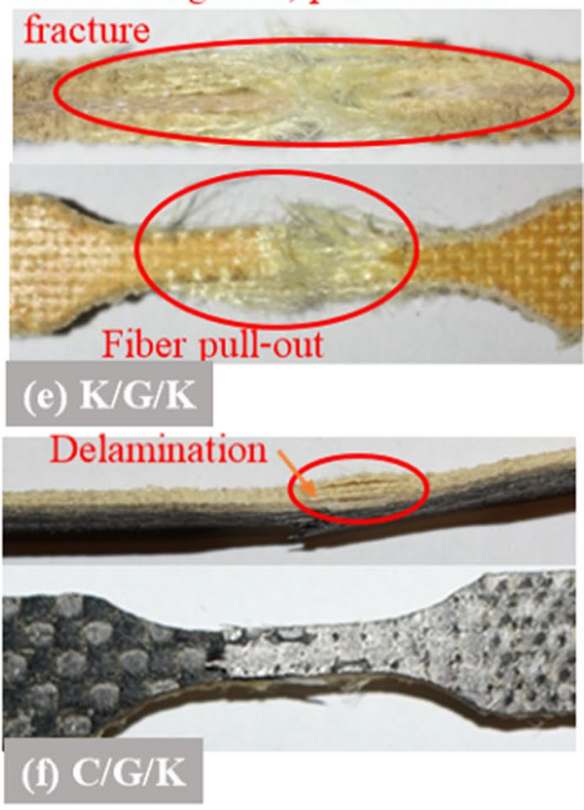

Delamination
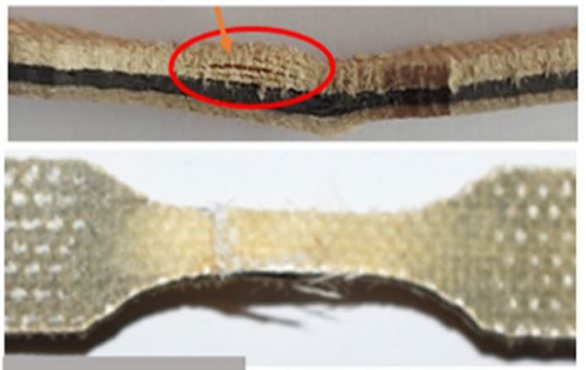

(g) $\mathrm{G} / \mathrm{C} / \mathrm{K}$

Fiber elongation, pull-out and fracture

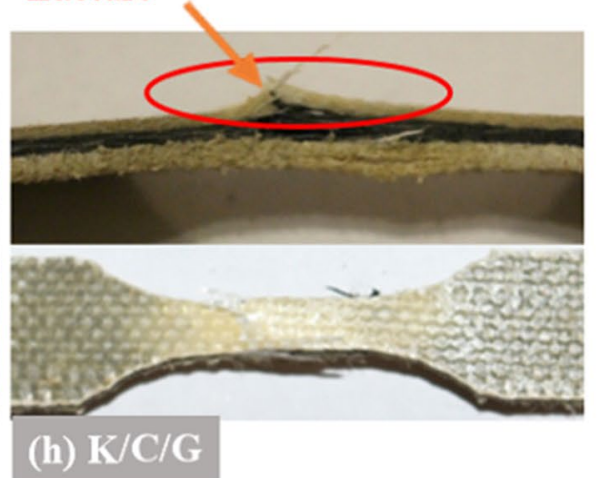

the $\sigma_{t}$ for the non-hybrid fabric composites are inline or in some cases slightly higher compared with the results of other researchers reported in the literature [6, 31-34]. The slight improvement in $\sigma_{t}$ can be attributed to fewer voids, better process parameters, and an efficient post-curing process. Due to these, the cross-link density in the composites increased, in addition to improved interface bonding between fiber and matrix. This leads to better load transfer. The tensile strength of the $\mathrm{G} / \mathrm{G} / \mathrm{G}$ specimen reported in this study is $27 \%$ higher compared to results reported by Balaganesan et al. [33]. The markable improved tensile strength performance of the $\mathrm{G} / \mathrm{G} / \mathrm{G}$ composite laminates compared to past research is due to the ballistic grade epoxy matrix formulation used in this study. 
The tensile strain $\left(e_{t}\right)$ was highest in the $\mathrm{K} / \mathrm{K} / \mathrm{K}$ specimen (23.4\%) among all specimens followed by the $\mathrm{C} / \mathrm{C} / \mathrm{C}$ specimen $(13.8 \%)$ and the least in the case of the $\mathrm{G} / \mathrm{C} / \mathrm{K}$ specimen $(7.8 \%)$. The specimens with a greater number of Kevlar layers showed more strain compared to other hybrid specimens with all three fiber reinforcements. This is because of the inherent tensile strain of Kevlar fibers.

Considering tensile modulus $\left(E_{t}\right)$ of the composites, it can be noticed that $\mathrm{C} / \mathrm{C} / \mathrm{C}$ composite specimen exhibited the highest value (17.9 GPa) followed by K/C/K $(15.1 \mathrm{GPa})$. The $\mathrm{G} / \mathrm{G} / \mathrm{G}$ composite sample offered a $E_{t}$ of $12 \mathrm{GPa}$. The least $E_{t}$ was observed in $\mathrm{K} / \mathrm{K} / \mathrm{K}$ specimen $(8.4 \mathrm{GPa})$. Hybrid composite specimens constituting all three types of reinforcement had a $E_{t}$ in the range 13.33-15 GPa; thus, hybridization proved useful to achieve $a \mathrm{E}_{\mathrm{t}}$ considerably higher than plain Kevlar samples.

The area under the tensile stress-strain curve of a particular composite represents the ability of the respective composite to absorb mechanical energy up to the point of failure, which is the tensile toughness. It is an important property for the impact resistance behavior of FRP composites [35]. In this study, tensile toughness was measured by calculating the area under the tensile stress-strain curve for each composite specimen, and this value was used as an input parameter for material properties during simulation of high-velocity impacts. This is a simple method where a trend line curve matching the actual stress strain curve for a specimen is plotted, and the area under this curve is considered the toughness value for the specimen. Unlike $\sigma_{t}$, the highest toughness is observed in $\mathrm{K} / \mathrm{K} / \mathrm{K}$ composite specimens $\left(42.3 \times 10^{-3} \mathrm{~J}^{-3 m^{-3}}\right)$ followed by $\mathrm{C} / \mathrm{C} / \mathrm{C}$ composite $\left(41.6 \times 10^{-3} \mathrm{~J}_{\mathrm{mm}} \mathrm{m}^{-3}\right)$. The least tensile toughness of

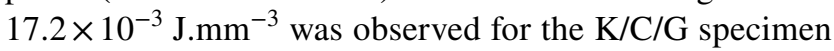
containing all three-fabric reinforcements. From the point of view of both tensile strength and toughness, the $\mathrm{C} / \mathrm{C} / \mathrm{C}$ and $\mathrm{K} / \mathrm{K} / \mathrm{K}$ laminates exhibited the best performance. Hybridization with glass fabric layers did not enhance significantly the tensile strength and toughness values, but tensile modulus values were considerably higher (29-44\%) than observed for $\mathrm{K} / \mathrm{K} / \mathrm{K}$ specimen.

The digital photographs of non-hybrid and hybrid fabric epoxy composite-fractured tensile specimen images are shown in Figs. 4a-h. The failure is mainly due to brittle fracture, and the plane of fracture is almost perpendicular to the axis of loading noticed in the $\mathrm{C} / \mathrm{C} / \mathrm{C}$ composite specimen as shown in Fig. 4a. High elongation followed by pull-out of fiber is observed in the $\mathrm{K} / \mathrm{K} / \mathrm{K}$ composite sample as shown in Fig. 4b. Also, the high tensile strain behavior is evident in the tensile stress-strain plot as shown in Fig. 2. The G/G/G composite showed brittle shear fracture with matrix crack as mentioned in Fig. 4c. Also, the damaged zone in $\mathrm{K} / \mathrm{K} / \mathrm{K}$ specimen is larger compared to $\mathrm{G} / \mathrm{G} / \mathrm{G}$ and $\mathrm{C} / \mathrm{C} / \mathrm{C}$ samples. The fiber elongation, pull-out, and further fiber fracture are observed in Kevlar plies of $\mathrm{K} / \mathrm{C} / \mathrm{K}$ and $\mathrm{K} / \mathrm{G} / \mathrm{K}$ composite samples as shown in Fig. 4d, e. The delamination between plies at the interface is observed in hybrid fabric epoxy composites $(\mathrm{C} / \mathrm{G} / \mathrm{K}, \mathrm{G} / \mathrm{C} / \mathrm{K}$, and $\mathrm{K} / \mathrm{C} / \mathrm{G})$ consisting of three types of fabrics as shown in Fig. $4 \mathrm{f}-\mathrm{h}$. This is due to the difference in the tensile behavior of carbon, Kevlar, and glass fabric. The poor wetting and non-compatibility are also reasons for delamination. The failure due to delamination of plies, fiber elongation, and further pull-out in Kevlar fabric and fiber damage are general types of failure modes observed in the hybrid fabric composites.

The scanning electron microscopic (SEM) images of the tensile fractured surface are presented in Fig. 5a-d. The $\mathrm{C} / \mathrm{C} / \mathrm{C}$ composite specimen failed due to sudden and rapid brittle fracture (refer to Fig. 5a). The same type of tensile failure is commonly reported in the literature for neat carbon epoxy composites [36]. The G/G/G composite specimens showed brittle and shear failure of the matrix due to matrix cracks (Fig. 5b). Similar kinds of failures noticed in the literature for neat glass-epoxy composites [37]. The K/K/K composite specimen showed fiber elongation; further, fiber pull-out was observed to be the common mode of failure in Kevlar epoxy composites [38]. Similar to other studies conducted in past research, the major modes of failure observed in this work were fiber breakage, pull-out, delamination, and matrix cracks, which were confirmed through the SEM images.

\subsection{Flexural behavior}

Flexural test results reflect the combined effects of tensile, compressive, and shear properties. The flexural modulus $\left(E_{f}\right)$ represents resistance to bending deformation [39]. Thus, flexural properties are important for the ballistic application. The flexural stress $\left(\sigma_{f}\right)$ and flexural strain $\left(e_{f}\right)$ of the non-hybrid and hybrid fabric epoxy composite laminates are calculated using Eqs. 5 and 6, respectively (ASTM D790).

$\sigma_{f}=\frac{3 P L}{2 b d^{2}}$

$e_{f}=\frac{6 D d}{L^{2}}$

where $P$ is the flexural load $(\mathrm{N}), L$ is the support span length $(\mathrm{mm}), b$ is the width of the specimen $(\mathrm{mm}), d$ is the thickness of the laminate $(\mathrm{mm}), D$ is the deflection $(\mathrm{mm})$.

The flexural stress-strain plot of non-hybrid and hybrid fabric epoxy composites is shown in Fig. 6. The $\mathrm{C} / \mathrm{C} / \mathrm{C}$ and G/G/G composite specimens subjected to flexural loading, the carbon and glass layers exhibited brittle fracture as observed in case of tensile tests. The area of damage was localized and concentrated below the loading nose. In case 
Fig. 5 SEM images of composite laminates at tensile fracture zone. a $\mathrm{C} / \mathrm{C} / \mathrm{C}, \mathbf{b} \mathrm{G} / \mathrm{G} / \mathrm{G}, \mathbf{c}$ $\mathrm{K} / \mathrm{K} / \mathrm{K}$ and $\mathbf{d} \mathrm{C} / \mathrm{G} / \mathrm{K}$
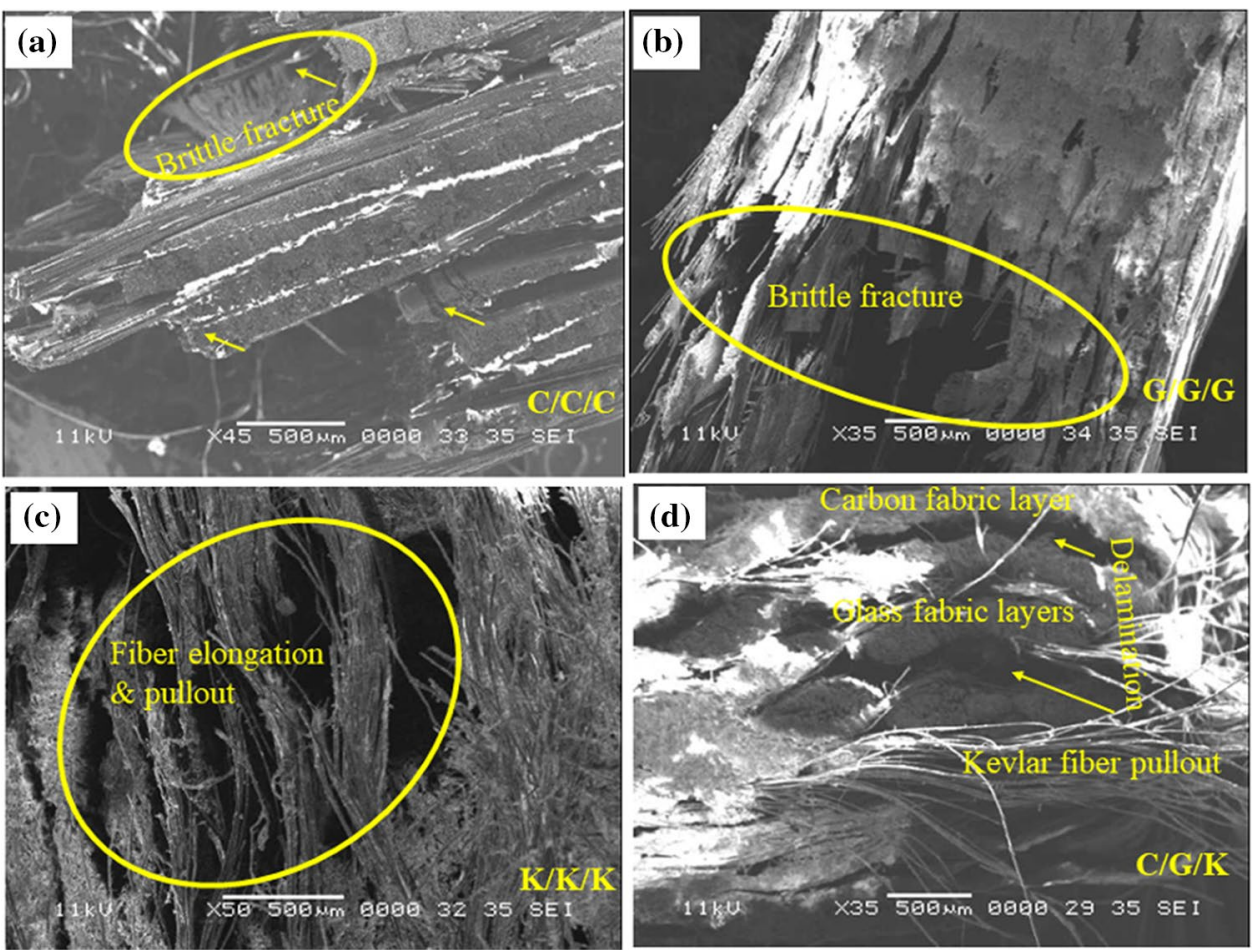

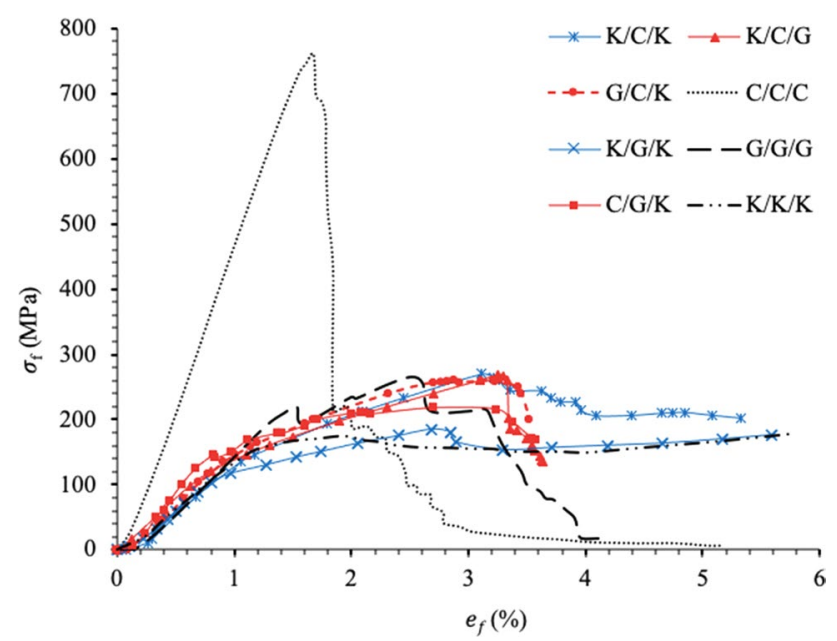

Fig. 6 Flexural stress-strain plot of non-hybrid and hybrid fabric epoxy composites

of $\mathrm{K} / \mathrm{K} / \mathrm{K}$ specimen, no brittle damage was observed, but fiber elongation and delamination were predominant. In hybrid fabric epoxy samples observed all the three modes of failure.

The $\sigma_{f}$ and $E_{f}$ for all the non-hybrid and hybrid fabric epoxy composites are shown in Fig. 7, and the photographs of fractured flexural specimens are depicted in Fig. 8.

In flexural test, the top layers of the composite specimens are subjected to compression and bottom layers subjected to tensile loading. The $\mathrm{C} / \mathrm{C} / \mathrm{C}$ composite specimen

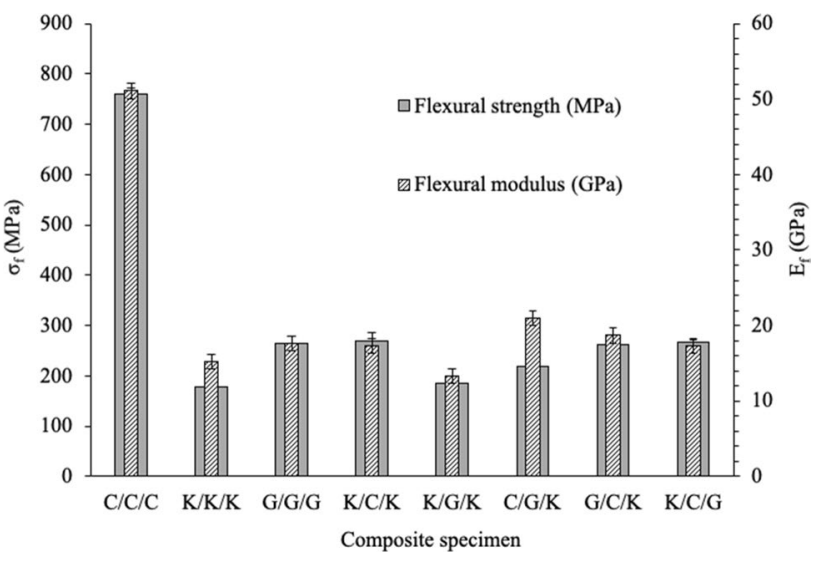

Fig. 7 Flexural strength and modulus of non-hybrid and hybrid fabric epoxy composites

exhibited the highest $\sigma_{f}$ (761 MPa) compared to all other composite specimens considered in this study. Carbon fabric is able to take more tensile and compressive load. It transfers the load up to the bottom layer till the fracture of the bottom layer. Figure 8 shows the images of the composite specimens subjected to flexural loading. In the figure, $\mathrm{w}$ and $\mathrm{t}$ denote the width and thickness of the specimen, respectively. As depicted in Fig. $8 \mathrm{a}$, the $\mathrm{C} / \mathrm{C} / \mathrm{C}$ composite specimen failed due to high tensile stress at the bottom layer developed during the flexural test and also interface crack generated at the bottom layer. These results are almost agreeable with the results reported by 


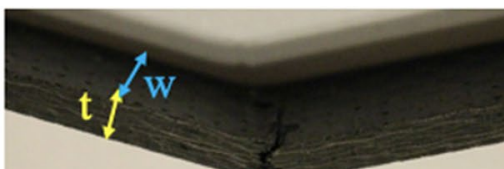

Fiber fracture

(a) $\mathrm{C} / \mathrm{C} / \mathrm{C}$

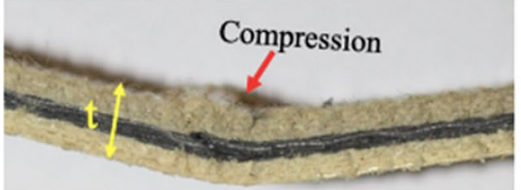

(d) $\mathrm{K} / \mathrm{C} / \mathrm{K}$

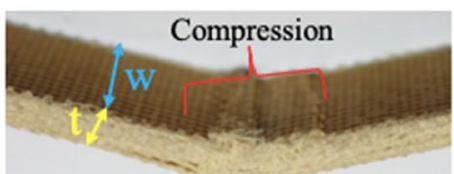

(b) $K / K / K$

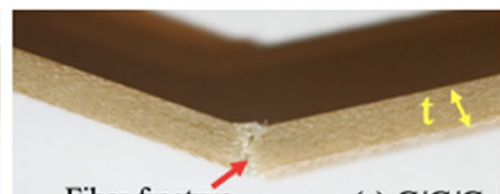

Fiber fracture

(c) $G / G / G$

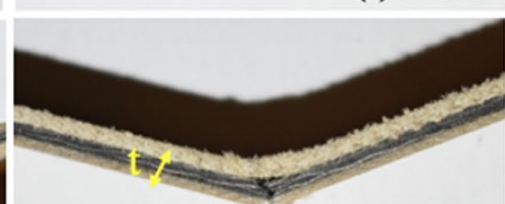

Fiber fracture

(f) $\mathrm{K} / \mathrm{C} / \mathrm{G}$

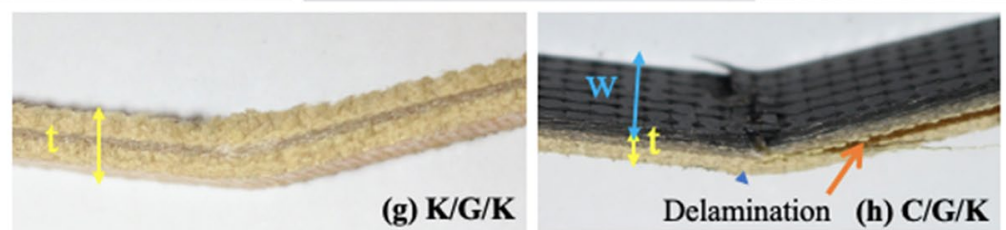

Fig. 8 Images of fractured flexural test specimens of non-hybrid and hybrid fabric epoxy composites

Dong et al. [40]. The K/K/K composite specimen had the least $\sigma_{f}(177 \mathrm{MPa})$ due to failure of the Kevlar fibers in the top layer because of compression stress and also observed delamination at the bottom layers as shown in Fig. 8b. These results are in line with the results reported by Sharma et al. [38] and Mourad et al. [41, 42]. The G/G/G specimen had a $\sigma_{f}$ of $265 \mathrm{MPa}$, which is considerably higher than $\sigma_{f}$ of $\mathrm{K} / \mathrm{K} / \mathrm{K}$ specimen $(177 \mathrm{MPa})$; this is due to the higher value of glass fiber $\sigma_{t}$ and the high flexibility of the Kevlar fibers, which did not fracture even beyond a deformation limit of $25 \mathrm{~mm}$. The brittle fracture with pull-out of fiber observed in the G/G/G composite specimen is shown in Fig. 8c. The results obtained for G/G/G in this study are slightly higher as compared to the values reported by Zhang et al. [6] (218 MPa) and Afrouzian et al. [34] (155 MPa).

Considering hybrid composites, the $\mathrm{C} / \mathrm{G} / \mathrm{K}$ showed that low $\sigma_{f}$ of $218 \mathrm{MPa}$ can be attributed to the fact that the carbon layer on the top face does not aid in crack bridging in the middle and bottom layers having low-strength glass and Kevlar layers, respectively. This leads to delamination and early failure as shown in Fig. 8h. Meanwhile, hybrid fabric epoxy composite specimens having carbon plies in the middle layer, such as $\mathrm{K} / \mathrm{C} / \mathrm{K}, \mathrm{G} / \mathrm{C} / \mathrm{K}$, and $\mathrm{K} / \mathrm{C} / \mathrm{G}$, showed $\sigma_{\mathrm{f}}$ of $270 \mathrm{MPa}, 261 \mathrm{MPa}$, and $266 \mathrm{MPa}$, respectively, which is higher than hybrid fabric epoxy composite samples having glass or Kevlar fabrics in the middle layers. This is due to the resistance to axial compressive strain offered by the high modulus carbon fabrics, which causes considerable increased compressive strength. Similarly, tensile stiffness of Kevlar composites can be improved by hybridizing with carbon or glass layers, which can be beneficial in structural applications [8].
Srivathsan et al. [9] reported that hybridizing glass fabric composites with carbon layers significantly improved the $\sigma_{f}$. In the present study, Kevlar fabric was also used along with glass and carbon fabrics. Hence, the $\sigma_{f}$ of hybrid epoxy composites $\mathrm{C} / \mathrm{G} / \mathrm{K}, \mathrm{K} / \mathrm{C} / \mathrm{G}$, and $\mathrm{G} / \mathrm{C} / \mathrm{K}$ are lower than G/G/G composite. From Table 2, it can also be noted that even though the $\sigma_{t}$ of carbon/epoxy is higher compared to glass/epoxy, the $\sigma_{f}$ of $\mathrm{C} / \mathrm{G} / \mathrm{K}(218 \mathrm{MPa})$ is lower than that of $\mathrm{G} / \mathrm{C} / \mathrm{K}(261 \mathrm{MPa})$ due to the brittle nature of carbon layer subjected to compressive loading on the top layer leading to reduced energy absorption [10].

It is observed that the maximum $\sigma_{f}$ of the composite specimen corresponds to the maximum load tolerated by the specimen at the lower surface, below the loading nose, where the tensile stresses of the specimen are the highest. Zhang et al. [6] in their study on carbon- and glass-reinforced hybrid and non-hybrid composites attributed that this reason for specimens with higher $\sigma_{t}$ fabrics at the bottom layer has higher $\sigma_{f}$. This is also true for $\mathrm{C} / \mathrm{C} / \mathrm{C}$ composite specimens. The tensile and flexural properties of non-hybrid and hybrid fabric epoxy composites studied in this work are compared with the past work results and listed in Table 2. It is found that the non-hybrid fabric epoxy composite results obtained by this work are almost in line with the results available in the literature. However, for the hybrid fabric epoxy composites studied in this research (three types of fabrics with different lay-up sequences), limited literature was found for comparison.

\subsection{Hardness of the composites}

The Rockwell-B hardness of non-hybrid and hybrid fabric epoxy composites is studied by applying a $100 \mathrm{~kg}-\mathrm{f}$ on the 
Table 2 Tensile and flexural properties of non-hybrid and hybrid fabric epoxy composites

\begin{tabular}{|c|c|c|c|c|c|c|c|}
\hline $\begin{array}{l}\text { Composite } \\
\text { Specimen }\end{array}$ & $\sigma_{t}(\mathrm{MPa})$ & $\begin{array}{l}E_{t} \\
(\mathrm{GPa})\end{array}$ & $\begin{array}{l}\text { Tough- } \\
\text { ness }(\mathrm{J} / \\
\left.\mathrm{mm}^{3} \times 10^{-3}\right)\end{array}$ & $\begin{array}{l}\sigma_{t}(\mathrm{MPa}) \\
\text { as per literature }\end{array}$ & $\begin{array}{l}\sigma_{f} \\
(\mathrm{MPa})\end{array}$ & $\begin{array}{l}E_{f} \\
(\mathrm{GPa})\end{array}$ & $\begin{array}{l}\sigma_{f}(\mathrm{MPa}) \\
\text { as per literature }\end{array}$ \\
\hline $\mathrm{C} / \mathrm{C} / \mathrm{C}$ & $615 \pm 11$ & $17.9 \pm 0.4$ & $41.6 \pm 0.9$ & $\begin{array}{l}710[30] \\
420[6]\end{array}$ & $761 \pm 10$ & $51.1 \pm 1.3$ & $\begin{array}{l}629[47] \\
701[48] \\
760[40]\end{array}$ \\
\hline $\mathrm{K} / \mathrm{K} / \mathrm{K}$ & $402 \pm 5$ & $8.4 \pm 0.1$ & $42.3 \pm 3.4$ & $\begin{array}{l}350[31] \\
380[32]\end{array}$ & $177 \pm 15$ & $15.2 \pm 0.2$ & $\begin{array}{l}161[38] \\
145[41] \\
141[42]\end{array}$ \\
\hline G/G/G & $346 \pm 13$ & $12 \pm 0.1$ & $18.7 \pm 2.6$ & $\begin{array}{l}250[33] \\
237[34] \\
200[6]\end{array}$ & $265 \pm 11$ & $17.6 \pm 0.5$ & $\begin{array}{l}218[6] \\
155[34]\end{array}$ \\
\hline $\mathrm{K} / \mathrm{C} / \mathrm{K}$ & $376 \pm 8$ & $15.1 \pm 0.1$ & $26.8 \pm 0.1$ & - & $270 \pm 15$ & $17.3 \pm 0.8$ & - \\
\hline $\mathrm{C} / \mathrm{G} / \mathrm{K}$ & $362 \pm 2$ & $14.9 \pm 0.1$ & $18.4 \pm 0.7$ & - & $218 \pm 10$ & $21 \pm 0.2$ & - \\
\hline $\mathrm{G} / \mathrm{C} / \mathrm{K}$ & $354 \pm 4$ & $15 \pm 0.1$ & $18.9 \pm 2.5$ & - & $261 \pm 2$ & $18.7 \pm 0.5$ & - \\
\hline $\mathrm{K} / \mathrm{C} / \mathrm{G}$ & $349 \pm 12$ & $13.3 \pm 0.1$ & $17.2 \pm 0.5$ & - & $266 \pm 2$ & $17.3 \pm 0.8$ & - \\
\hline $\mathrm{K} / \mathrm{G} / \mathrm{K}$ & $289 \pm 10$ & $11.9 \pm 0.7$ & $20.7 \pm 1.7$ & - & $186 \pm 9$ & $13.3 \pm 0.6$ & - \\
\hline
\end{tabular}

specimen of size $25 \times 25 \times 3 \mathrm{~mm}^{3}$ using a hardened steel hemispherical ball indenter of 1/16 inch diameter. Figure 9 shows the composite specimens after hardness tests. Each sample was indented at multiple spots (at least 5 times), and the mean value of the Rockwell-B hardness number for all composite laminates is considered. It is observed that among all specimens, $\mathrm{K} / \mathrm{K} / \mathrm{K}, \mathrm{C} / \mathrm{C} / \mathrm{C}, \mathrm{K} / \mathrm{C} / \mathrm{K}, \mathrm{K} / \mathrm{C} / \mathrm{G}$ and $\mathrm{K} / \mathrm{G} / \mathrm{K}$ samples exhibited RHN-B in the range of 50-53. But, $\mathrm{C} / \mathrm{G} / \mathrm{K}$ and $\mathrm{G} / \mathrm{C} / \mathrm{K}$ showed lower than other hybrid composite specimens. The lowest RHN-B is observed for $\mathrm{G} / \mathrm{G} / \mathrm{G}$ specimen. This is attributed to the specimens with more Kevlar and carbon layers that exhibited slightly higher hardness values compared to specimens with glass layers. Also, it is noticed that hybridization did not have any considerable impact on the hardness values. The hardness is mainly governed by the fabric layer on the top surface that was indented and also the type of resin used. (In this study, it was epoxy for all laminate specimens.)

\subsection{High-velocity impact}

The non-hybrid and hybrid fabric composite laminates for ballistic impact simulations were modeled using SolidWorks 2020 software. A 3-mm-thick laminate consisting of 15 plies of fabric (each ply $0.2 \mathrm{~mm}$ thick) similar to the laminates fabricated for the experimental tests was modeled. Using the assembly feature in the modeling platform, the 15 fabric plies were assembled to form the laminate. Each ply was bonded using the epoxy matrix formulation. AISI 1006 steel bullet was considered as a projectile and modeled to resemble a 9-mm Parabellum bullet as per STANAG 4090 [43] standard with hemispherical end diameter: $9 \mathrm{~mm}$, total length: $19 \mathrm{~mm}$ and mass: $8.78 \mathrm{~g}$. The projectile and specimen with all dimensions are shown in Fig. 10.

The high-velocity impact simulation of the bullet on the composite laminate target was performed at impact velocities of $100 \mathrm{~m} . \mathrm{s}^{-1}, 250 \mathrm{~m} . \mathrm{s}^{-1}$ and $350 \mathrm{~m} . \mathrm{s}^{-1}$ on explicit
Fig. 9 Hardness-tested nonhybrid and hybrid composite specimens

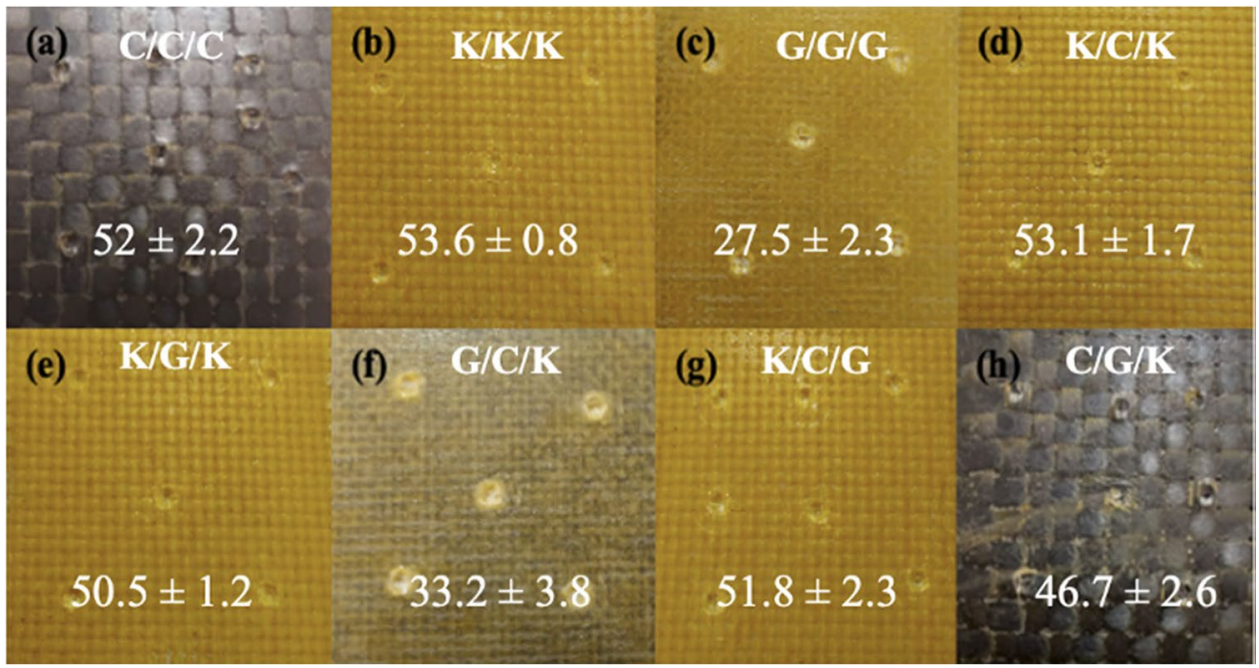




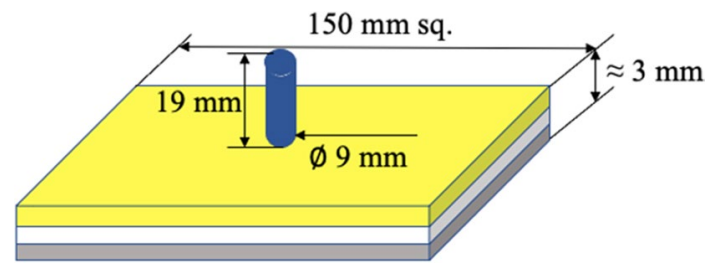

Fig. 10 Projectile and composite laminate with dimensions

dynamics platform of LS-DYNA software. Various physical and mechanical properties such as density, tensile, and flexural properties assigned to the specimens were derived from the experimental tests performed on the laminates and are listed in Table 3.

The FE run time and accuracy of results depend on the size and shape of the selected mesh. Various shapes and sizes of meshes are available among which triangular mesh of size $2 \mathrm{~mm}$ for composite laminate and $0.5 \mathrm{~mm}$ for the bullet was selected in this study. These mesh parameters were chosen keeping in mind the time taken for solution processing and the available computer system processor capacity.

The type of contact between projectile and the composite laminate was defined as *CONTACT_AUTOMATIC SURFACE_TO_SURFACE, with a coefficient friction of 0.2. The step time in simulation used in this study was $0.1 \mathrm{~s}$, which is the time required for the propagation of wave through the discretized element and an end-time of $5 \mathrm{~s}$ was assigned, after which the simulation terminates. Similarly, hourglass control type IHQ 5 feature was defined in the simulation as per the recommendation of LS-DYNA platform for high-velocity impact simulations. Not defining hourglass feature will lead to zero-energy deformation where individual elements will be severely damaged, while the overall mesh section does not show any deformation.

Material model "MAT 18_POWER_LAW_PLASTICITY_" was used for the composite laminates. This model takes into consideration elastoplastic behavior with isotropic hardening of the material with a function of plastic strain. This material obeys Eq. (7). $\sigma_{y}=k \varepsilon^{n}=k\left(\in_{y p}+\bar{\varepsilon}^{p}\right)^{n}$

where $\sigma_{y}$ is the yield strength, $\in_{y p}$ is the elastic strain and $\bar{\varepsilon}^{p}$ is the effective plastic strain (logarithmic), $\mathrm{k}$ is the strengthening coefficient and $\mathrm{n}$ is the hardening exponent. Material model "*MAT_RIGID_"was assigned to the projectile.

The edges of the laminate were fixed to restrict any linear or rotational motion to simulate the impact event as performed during real experiments. "SPC" feature on LS-DYNA was used to activate the fixed supports on the laminate edges.

Energy absorption during projectile impact $\left(E_{\mathrm{ab}}\right)$ is one of the main factors to measure the degree of damage in composite laminates when subjected to such ballistic events. Impact energy $\left(E_{i}\right)$ is the kinetic energy of the projectile that is acting on the composite just before impact, while the kinetic energy lost by the projectile is the amount of energy absorbed $\left(E_{\mathrm{ab}}\right)$ within the composite at the end of an impact event [44]. The difference in the kinetic energies of the projectile before and after impact determines the energy absorbed by the laminate. In this study, energy absorbed by the laminate is determined through Eq. (8).

$E_{\mathrm{ab}}=\frac{1}{2} m\left(V_{i}^{2}-V_{r}^{2}\right)$

where $m$ is the mass of the projectile, $V_{i}$ and $V_{r}$ are the initial and residual velocities of the projectile before and after impact, respectively.

The results of the impact tests in terms of projectile residual velocities, energy absorption by the composite laminates and their deformation are presented in Table 4 . Among the eight types of laminates tested, K/K/K specimen had the best impact performance as noted from its energy absorption and residual velocity results for impact velocities of $100 \mathrm{~m} . \mathrm{s}^{-1}, 250 \mathrm{~m} . \mathrm{s}^{-1}$ and $350 \mathrm{~m} . \mathrm{s}^{-1}$ considered in this study. This is due to the higher failure strain in Kevlar fabric compared to carbon and glass fabrics. This behavior for non-hybrid composites was also noted by Bulut et al. [45] who reported the energy absorption
Table 3 Mechanical properties of composites considered for simulation

\begin{tabular}{llll}
\hline Mechanical property & \multicolumn{2}{l}{ Composite layer } & \\
\cline { 2 - 4 } & Carbon/epoxy & Kevlar/epoxy & Glass/epoxy \\
\hline Density $\left(\mathrm{kg} \cdot \mathrm{m}^{-3}\right)$ & 1357 & 1052 & 1641 \\
Tensile strength $(\mathrm{MPa})$ & 615 & 402 & 346 \\
Young's modulus $(\mathrm{GPa})$ & 17.9 & 8.4 & 12.0 \\
Poisson's ratio & 0.31 & 0.37 & 0.25 \\
Tensile toughness $\left(\times 10^{-3} \mathrm{~J}^{-\mathrm{mm}^{-3}}\right)$ & 41.6 & 42.3 & 18.7 \\
Flexural strength $(\mathrm{MPa})$ & 761 & 177 & 265 \\
Flexural modulus $(\mathrm{GPa})$ & 51.1 & 15.2 & 17.6 \\
\hline
\end{tabular}


Table 4 Residual velocity and energy absorption of the nonhybrid and hybrid fabric epoxy laminates

\begin{tabular}{|c|c|c|c|c|c|c|c|c|c|c|}
\hline \multirow[t]{2}{*}{ Sl. No. } & \multirow{2}{*}{$\begin{array}{l}\text { Composite } \\
\text { Specimen }\end{array}$} & \multicolumn{3}{|c|}{$V_{i}=100 \mathrm{~m} \cdot \mathrm{s}^{-1}$} & \multicolumn{3}{|c|}{$V_{i}=250 \mathrm{~m} \cdot \mathrm{s}^{-1}$} & \multicolumn{3}{|c|}{$V_{i}=350 \mathrm{~m} \cdot \mathrm{s}^{-1}$} \\
\hline & & $\begin{array}{l}E_{i} \\
(\mathrm{~J})\end{array}$ & $\begin{array}{l}V_{r} \\
\left(\mathrm{~m} \cdot \mathrm{s}^{-1}\right)\end{array}$ & $\begin{array}{l}E_{a b} \\
(J)\end{array}$ & $\begin{array}{l}E_{i} \\
(\mathrm{~J})\end{array}$ & $\begin{array}{l}V_{r} \\
\left(\mathrm{~m} \cdot \mathrm{s}^{-1}\right)\end{array}$ & $\begin{array}{l}E_{a b} \\
(J)\end{array}$ & $\begin{array}{l}E_{i} \\
(\mathrm{~J})\end{array}$ & $\begin{array}{l}V_{r} \\
\left(\mathrm{~m} \cdot \mathrm{s}^{-1}\right)\end{array}$ & $\begin{array}{l}E_{a b} \\
(J)\end{array}$ \\
\hline 1 & $\mathrm{~K} / \mathrm{K} / \mathrm{K}$ & 43.1 & 0 & 43.1 & 269.37 & 101.84 & 224.66 & 527.97 & 228.66 & 302.60 \\
\hline 2 & $\mathrm{C} / \mathrm{C} / \mathrm{C}$ & & 8.55 & 42.78 & & 131.79 & 194.51 & & 279.18 & 192.04 \\
\hline 3 & $\mathrm{G} / \mathrm{G} / \mathrm{G}$ & & 48.14 & 33.11 & & 165.13 & 151.85 & & 325.34 & 71.77 \\
\hline 4 & $\mathrm{~K} / \mathrm{G} / \mathrm{K}$ & & 0 & 43.1 & & 115.27 & 212.10 & & 236.04 & 287.825 \\
\hline 5 & $\mathrm{~K} / \mathrm{C} / \mathrm{K}$ & & 0 & 43.1 & & 127.62 & 199.16 & & 233.16 & 293.65 \\
\hline 6 & $\mathrm{G} / \mathrm{C} / \mathrm{K}$ & & 0 & 43.1 & & 130.99 & 195.42 & & 233.16 & 293.65 \\
\hline 7 & $\mathrm{C} / \mathrm{G} / \mathrm{K}$ & & 0 & 43.1 & & 130.71 & 195.72 & & 233.16 & 293.65 \\
\hline 8 & $\mathrm{~K} / \mathrm{C} / \mathrm{G}$ & & 46.40 & 33.82 & & 153.63 & 167.64 & & 335.90 & 41.67 \\
\hline
\end{tabular}

was highest in Kevlar/epoxy laminate followed by carbon/ epoxy and glass/epoxy composites, respectively, when subjected to impact tests.

Corresponding to impact velocity of $100 \mathrm{~m} \cdot \mathrm{s}^{-1}$, the projectile penetrated the specimen completely for $\mathrm{C} / \mathrm{C} / \mathrm{C}$, $\mathrm{K} / \mathrm{C} / \mathrm{G}$ and $\mathrm{G} / \mathrm{G} / \mathrm{G}$ specimens, and for all other laminates the projectile was arrested. But, at higher impact velocities of $250 \mathrm{~m} . \mathrm{s}^{-1}$ and $350 \mathrm{~m} . \mathrm{s}^{-1}$ all laminates were completely penetrated and the projectile ejected with residual velocities as presented in Table 4.

Considering the impact velocity of $350 \mathrm{~m} . \mathrm{s}^{-1}$ the $\mathrm{C} / \mathrm{C} / \mathrm{C}$ specimen recorded energy absorption value similar to $250 \mathrm{~m} . \mathrm{s}^{-1}$ impact, and for the K/C/G the energy absorption at $350 \mathrm{~m} . \mathrm{s}^{-1}$ was at par with results for $100 \mathrm{~m} . \mathrm{s}^{-1}$. Similarly, for the G/G/G energy absorption for $350 \mathrm{~m} . \mathrm{s}^{-1}$ was lower than resulted for $250 \mathrm{~m} . \mathrm{s}^{-1}$. This trend for nonhybrid glass and carbon composites is due to its highly brittle nature. As the impact velocity increases, the interaction time between projectile and laminate during impact reduces, resulting in higher residual velocities and lower energy absorption. Thus, G/G/G laminate had the least energy absorption behavior followed by $\mathrm{C} / \mathrm{C} / \mathrm{C}$ for nonhybrids, whereas $\mathrm{K} / \mathrm{C} / \mathrm{G}$ was the least energy absorbing among the hybrid specimens for all impact velocities. Also, considering two-fabric and three-fabric hybrid configurations, the two-fabric composites $\mathrm{K} / \mathrm{C} / \mathrm{K}$ and $\mathrm{K} / \mathrm{G} / \mathrm{K}$ exhibited better $E_{\mathrm{ab}}$ compared to all other specimens consisting of all three-fabric reinforcements such as $\mathrm{K} / \mathrm{C} / \mathrm{G}$, $\mathrm{C} / \mathrm{G} / \mathrm{K}$, and $\mathrm{G} / \mathrm{C} / \mathrm{K}$. Karahan et al. [26] reported similar behavior for hybrid composites that having Kevlar fabric in the front and back layers leads to improved $E_{\mathrm{ab}}$ and load-carrying capacity when subjected to impact loads. Ansari et al. [17] also observed that the impact resistance behavior of Kevlar and glass fabric hybrid composites is highest when the glass layer is sandwiched in between plies of Kevlar fabric. Thus, K/G/K composite can be considered a cost-efficient alternative to neat $\mathrm{K} / \mathrm{K} / \mathrm{K}$ laminates for impact resistance applications as the former's energy absorption behavior is similar to that of the latter.
The representative images of the ballistic impact simulations on $\mathrm{K} / \mathrm{K} / \mathrm{K}$ specimen are shown in Fig. 11. The sectioned view, showing the penetration of projectile into the laminate, is depicted in Fig. 11a. The deformation and effective stress in the specimen are presented in Fig. 11b, $c$, respectively. It was noted that stress was mainly concentrated in the primary yarns along the weft and warp directions intersecting at the point of projectile impact. Such an effect of impact concentrated in the primary yarns has been reported through various studies [1, 44].

It can be noted that specimens with more Kevlar plies exhibited better impact resistance behavior. It can also be noted that the specimens with Kevlar plies in the rear layers showed enhanced $E_{\mathrm{ab}}$ and lower $V_{r}$ compared to specimens with glass and carbon layers in the rear layers. This trend was also observed by researchers such as Muhi et al. [46] who conducted impact studies on hybrid fabric composites. They noted that as the Kevlar layer is pushed from the front face toward the back, the energy absorption increases, reaching the highest when Kevlar fabric is the last layer due to the increasing bending stiffness of the laminate when Kevlar is on the rear layer. Similarly, Randjbaran et al. [12] through ballistic impact experiments reported that, for hybrid composites comprising Kevlar, carbon and glass fabrics, the stacking of glass fabric as the first layer in the laminate was better than Kevlar. Similarly, carbon fabric is not recommended as the last layer, and the combination of carbon and glass in the middle layers was more efficient for ballistic applications.

Figure 12 shows the variation of residual velocity $\left(V_{r}\right)$ with impact velocity $\left(V_{i}\right)$ for the non-hybrid and hybrid fabric composite laminates impacted by projectile. The $V_{r}$ is one of the important parameters to quantify ballistic resistance of the composite laminates. The $\mathrm{G} / \mathrm{G} / \mathrm{G}, \mathrm{C} / \mathrm{C} / \mathrm{C}$ and $\mathrm{K} / \mathrm{C} / \mathrm{G}$ composite laminates showed exponential relation of $V_{r}$ with $V_{i}$. This is attributed to the brittleness of $\mathrm{G} / \mathrm{G} / \mathrm{G}$ and $\mathrm{C} / \mathrm{C} / \mathrm{C}$ composites, and other composites with glass fabric layer at the rear side. The variation of $V_{r}$ with respect to $V_{i}$ was found almost linear in $\mathrm{K} / \mathrm{K} / \mathrm{K}$ composite 
Fig. 11 Ballistic impact on $\mathrm{K} / \mathrm{K} / \mathrm{K}$ specimen at $250 \mathrm{~m} \cdot \mathrm{s}^{-1}$ : a sectioned view of laminate during impact, $\mathbf{b}$ resultant displacement in composite laminate and c effective stress in laminate after impact

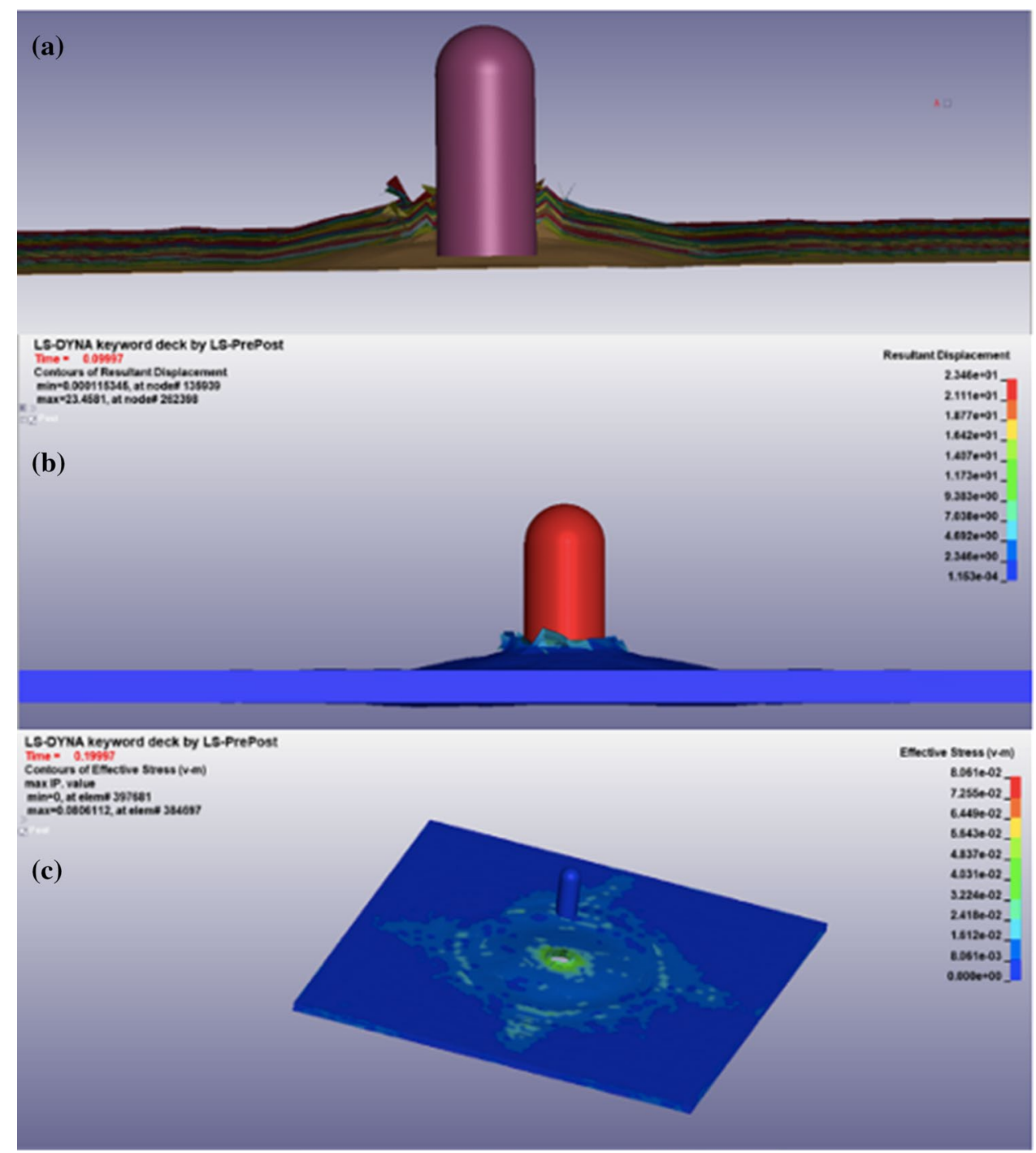

and hybrid composite with Kevlar fabric layer at the rear side of the composite. This also other shows that the penetration resistance offered by $\mathrm{K} / \mathrm{K} / \mathrm{K}, \mathrm{K} / \mathrm{G} / \mathrm{K}, \mathrm{C} / \mathrm{G} / \mathrm{K}$, $\mathrm{K} / \mathrm{C} / \mathrm{K}$ and $\mathrm{G} / \mathrm{C} / \mathrm{K}$ is better than $\mathrm{G} / \mathrm{G} / \mathrm{G}, \mathrm{C} / \mathrm{C} / \mathrm{C}$ and $\mathrm{K} / \mathrm{C} / \mathrm{G}$ composite laminates.

In the present study, fabric hybridization has shown to provide cost benefits in the fabrication of FRP composites, without sacrificing much on the $E_{\mathrm{ab}}$ property of the laminates. Even though neat Kevlar fabric composites are utilized for various applications such as development of aircraft components, bullet proofing and impact resistant composites, improved cost efficiency by hybridizing with cheaper reinforcements makes them more attractive and widely acceptable. Hybridizing glass fabrics in Kevlar/ epoxy composite provided material cost reduction of $21 \%$ compared to neat Kevlar/epoxy specimen, with a reduction in $E_{\mathrm{ab}}$ of only about $5 \%$ at impact velocities of $250 \mathrm{~ms}^{-1}$ and $350 \mathrm{~ms}^{-1}$. Improved cost efficiency and comparable impact performance make such hybrid composites ideal for defense-related applications such as body armor and helmets for law-enforcement personnel.

\section{Conclusion}

- Non-hybrid and hybrid composite laminates with different fabric stacking architecture were successfully fabricated using hand lay-up followed by hot-compression molding and found the laminates had low void content (maximum 5 vol.\%) and high fiber content (67-73 vol.\%).

- The $\mathrm{C} / \mathrm{C} / \mathrm{C}$ epoxy specimen had the highest tensile strength followed by neat $\mathrm{K} / \mathrm{K} / \mathrm{K}$ epoxy and the least strength when glass fabrics sandwiched between Kevlar fabric. However, sequence of architecture did not affect the tensile strength.

- The C/C/C epoxy and K/K/K epoxy laminates showed the highest and lowest flexural strength, respectively. Also, the flexural strength of hybrid composites consist- 


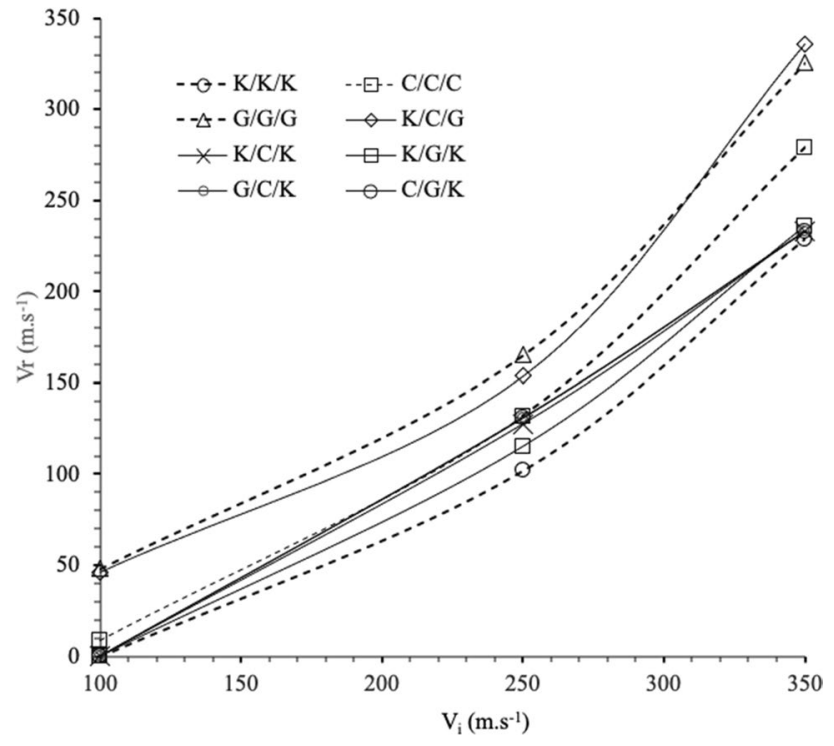

Fig. 12 Residual velocity versus impact velocity of non-hybrid and hybrid fabric epoxy composites

ing of Kevlar, carbon and glass was higher than that of $\mathrm{K} / \mathrm{K} / \mathrm{K}$

- Not much variation in hardness was noticed in $\mathrm{C} / \mathrm{C} / \mathrm{C}$ and $\mathrm{K} / \mathrm{K} / \mathrm{K}$ composites. However, the hardness was influenced by the top layer of hybrid composite, and the epoxy resin matrix was the same for all laminates. The G/G/G composite showed lowest hardness.

- As per the FEA results of ballistic impact tests, as the impact velocity increases the penetration resistance of hybrid and non-hybrid composite laminates decreased and vice versa.

- $\mathrm{K} / \mathrm{K} / \mathrm{K}$ specimen had the highest energy absorption compared to all composites when subjected to high-velocity impacts at $100 \mathrm{~ms}^{-1}, 250 \mathrm{~ms}^{-1}$, and $350 \mathrm{~ms}^{-1}$. Two-fabric hybrid composite $\mathrm{K} / \mathrm{G} / \mathrm{K}$ had energy absorption of about $5 \%$ lower than $\mathrm{K} / \mathrm{K} / \mathrm{K}$ and thus considered ideal for ballistic applications as it offered $21 \%$ reduction in material cost.

- The deterioration in penetration resistance is even more for brittle materials such as $\mathrm{G} / \mathrm{G} / \mathrm{G}$ and $\mathrm{C} / \mathrm{C} / \mathrm{C}$ composites with increasing impact velocities; also, the stacking sequence with Kevlar fabric in the rear side is beneficial in hybrid fabric composites.

- The effect of fabric stacking sequences derived from the FEA results was in good coordination with experimental observations reported by other researchers.

Considering the tensile, flexural, hardness and penetration resistance studies carried out in this work, it can be suggested that hybridization of reinforcement fabrics is beneficial from stiffness point of view for ballistic applications and also from the point of view of cost reduction by sandwiching cheaper glass fabric layers in Kevlar/epoxy composite without sacrificing other mechanical performance. However, further investigation is needed to optimize the process parameters for further improvement of the mechanical properties.

Acknowledgements The authors are grateful to Research \& Development Program (R\&DP), Manipal Academy of Higher Education, Dubai, UAE, for the financial assistance provided through research grant: R\&DP/MAHE DUBAI/RL-04/2019 for the procurement of materials used in this work.

Funding Open access funding provided by Manipal Academy of Higher Education, Manipal.

Open Access This article is licensed under a Creative Commons Attribution 4.0 International License, which permits use, sharing, adaptation, distribution and reproduction in any medium or format, as long as you give appropriate credit to the original author(s) and the source, provide a link to the Creative Commons licence, and indicate if changes were made. The images or other third party material in this article are included in the article's Creative Commons licence, unless indicated otherwise in a credit line to the material. If material is not included in the article's Creative Commons licence and your intended use is not permitted by statutory regulation or exceeds the permitted use, you will need to obtain permission directly from the copyright holder. To view a copy of this licence, visit http://creativecommons.org/licenses/by/4.0/.

\section{References}

1. Clifton S, Thimmappa BHS, Selvam R, Shivamurthy B (2020) Polymer nanocomposites for high-velocity impact applications-a review. Compos Commun. https://doi.org/10.1016/j.coco.2019.11. 013

2. Pandya KS, Pothnis JR, Ravikumar G, Naik NK (2013) Ballistic impact behavior of hybrid composites. Mater Des 44:128-135. https://doi.org/10.1016/j.matdes.2012.07.044

3. Safri SNA, Sultan MTH, Jawaid M, Jayakrishna K (2017) Impact behaviour of hybrid composites for structural applications: a review. Compos B Eng 133:112-121. https://doi.org/10.1016/j. compositesb.2017.09.008

4. Mehdikhani M, Petrov NA, Straumit I et al (2019) The effect of voids on matrix cracking in composite laminates as revealed by combined computations at the micro- and meso-scales. Compos A Appl Sci Manuf 117:180-192. https://doi.org/10.1016/j.compo sitesa.2018.11.009

5. Park CH, Lee WI (2012) Compression molding in polymer matrix composites. Woodhead Publishing Limited

6. Zhang J, Chaisombat K, He S, Wang CH (2012) Hybrid composite laminates reinforced with glass/carbon woven fabrics for lightweight load bearing structures. Mater Des 36:75-80. https:// doi.org/10.1016/j.matdes.2011.11.006

7. Murugan R, Ramesh R, Padmanabhan K (2016) Investigation of the mechanical behavior and vibration characteristics of thin walled glass/carbon hybrid composite beams under a fixed-free boundary condition. Mech Adv Mater Struct 23:909-916. https:// doi.org/10.1080/15376494.2015.1056394

8. Valença SL, Griza S, de Oliveira VG et al (2015) Evaluation of the mechanical behavior of epoxy composite reinforced with Kevlar plain fabric and glass/Kevlar hybrid fabric. Compos B Eng 70:1-8. https://doi.org/10.1016/j.compositesb.2014.09.040 
9. Srivathsan A, Vijayaram B, Ramesh R, Gokuldass (2017) Investigation on mechanical behavior of woven fabric glass/kevlar hybrid composite laminates made of varying fibre inplane orientation and stacking sequence. Mater Today Proc 4:8928-8937. https://doi. org/10.1016/j.matpr.2017.07.244

10. Bulut M, Erkliğ A (2017) An experimental investigation on damage characteristics of laminated hybrid composites subjected to low velocity impact. Poly Compos 39:3129-3139

11. Yanen C, Solmaz MY (2017) Ballistic performance of 21 layered hybrid composites. 12th Int Conf Latest Trends Eng Technol. https://doi.org/10.15242/iie.e0517007

12. Randjbaran E, Zahari R, Abdul Jalil NA, Abang Abdul Majid DL (2014) Hybrid composite laminates reinforced with Kevlar/ carbon/glass woven fabrics for ballistic impact testing. Sci World J. https://doi.org/10.1155/2014/413753

13. Shi Y, Soutis C (2017) Modelling low velocity impact induced damage in composite laminates. Mech Adv Mater Mod Processes. https://doi.org/10.1186/s40759-017-0029-x

14. Sorrentino L, Bellini C, Corrado A et al (2014) Ballistic performance evaluation of composite laminates in kevlar 29. Proced Eng 88:255-262. https://doi.org/10.1016/j.proeng.2015.06.048

15. Bandaru AK, Ahmad S (2017) Ballistic impact behaviour of thermoplastic kevlar composites: parametric studies. Proced Eng 173:355362. https://doi.org/10.1016/j.proeng.2016.12.029

16. Kumar S, Gupta DS, Singh I, Sharma A (2010) Behavior of kevlar/ epoxy composite plates under ballistic impact. J Reinf Plast Compos 29:2048-2064. https://doi.org/10.1177/0731684409343727

17. Ansari MM, Chakrabarti A (2017) Impact behaviour of GFRP and Kevlar/epoxy sandwich composite plate: experimental and FE analyses. J Mech Sci Technol 31:771-776. https://doi.org/10.1007/ s12206-017-0128-y

18. Özbek Ö, Doğan NF, Bozkurt ÖY (2020) An experimental investigation on lateral crushing response of glass/carbon intraply hybrid filament wound composite pipes. J Braz Soc Mech Sci Eng. https:// doi.org/10.1007/s40430-020-02475-3

19. Nurazzi NM, Asyraf MRM, Khalina A et al (2021) A review on natural fiber reinforced polymer composite for bullet proof and ballistic applications. Polymers 13:1-42. https://doi.org/10.3390/polym 13040646

20. ASTM D3171-15 (2015) Standard test methods for constituent content of composite materials. ASTM Int, West Conshohocken, PA. https://www.astm.org/Standards/D3171.htm

21. ASTM International (2016) ASTM D638-14 standard test method for tensile properties of plastics. ASTM Int 82:1-15. https://doi.org/ 10.1520/D0638-14.1

22. ASTM D790-03 (2003) Standard test methods for flexural properties of unreinforced and reinforced plastics and electrical insulation materials. ASTM Int, West Conshohocken, PA. https://www.astm. org/DATABASE.CART/HISTORICAL/D790-03.htm

23. Mehdikhani M, Gorbatikh L, Verpoest I, Lomov SV (2019) Voids in fiber-reinforced polymer composites: a review on their formation, characteristics, and effects on mechanical performance. J Compos Mater 53:1579-1669. https://doi.org/10.1177/0021998318772152

24. Bulut M, Erkliğ A (2018) The investigation of quasi-static indentation effect on laminated hybrid composite plates. Mech Mater 117:225-234. https://doi.org/10.1016/j.mechmat.2017.11.005

25. He HW, Gao F (2015) Effect of fiber volume fraction on the flexural properties of unidirectional carbon fiber/epoxy composites. Int J Polym Anal Charact 20:180-189. https://doi.org/10.1080/10236 66X.2015.989076

26. Karahan M, Yildirim K (2015) Low velocity impact behaviour of aramid and UHMWPE composites. Fibres Text East Eur 23:97-105. https://doi.org/10.5604/12303666.1152522

27. Priya IIM, Vinayagam BK (2018) Enhancement of bi-axial glass fibre reinforced polymer composite with graphene platelet nanopowder modifies epoxy resin. Adv Mech Eng 10:1-10. https:// doi.org/10.1177/1687814018793261

28. Gollins K (2014) Comparison of manufacturing techniques for composites subjected to high speed impact. City University of New York. https://academicworks.cuny.edu/cc_etds_theses/640/

29. Czél G, Jalalvand M, Wisnom MR (2016) Design and characterisation of advanced pseudo-ductile unidirectional thin-ply carbon/ epoxy-glass/epoxy hybrid composites. Compos Struct 143:362-370. https://doi.org/10.1016/j.compstruct.2016.02.010

30. Kadlec M, Hron R, Guadagno L (2016) Mechanical properties of a carbon fabric-reinforced epoxy composite with carbon nanotubes and a flame retardant. Int J Struct Integr 7:630-644. https://doi.org/ 10.1108/IJSI-09-2015-0029

31. Sikarwar RS, Velmurugan R, Madhu V (2012) Experimental and analytical study of high velocity impact on Kevlar/Epoxy composite plates. Cent Eur J Eng 2:638-649. https://doi.org/10.2478/ s13531-012-0029-x

32. Nunes SG, Scazzosi R, Manes A et al (2019) Influence of projectile and thickness on the ballistic behavior of aramid composites: experimental and numerical study. Int J Impact Eng 132:103307. https:// doi.org/10.1016/j.jijimpeng.2019.05.021

33. Balaganesan G, Velmurugan R, Srinivasan M et al (2014) Energy absorption and ballistic limit of nanocomposite laminates subjected to impact loading. Int J Impact Eng 74:57-66. https://doi.org/10.1016/j. ijimpeng.2014.02.017

34. Afrouzian A, Movahhedi Aleni H, Liaghat G, Ahmadi H (2017) Effect of nano-particles on the tensile, flexural and perforation properties of the glass/epoxy composites. J Reinf Plast Compos 36:900-916. https:// doi.org/10.1177/0731684417694753

35. Sharma P, Mali HS, Dixit A (2021) Mechanical behavior and fracture toughness characterization of high strength fiber reinforced polymer textile composites. Springer, Berlin Heidelberg

36. Maria J, de Paiva F, Mayer S, Cerqueira M (2006) Comparison of tensile strength of different carbon fabric reinforced epoxy composites jane. Mater Res 9:83-89

37. Yousefi J, Ahmadi M, Shahri MN et al (2014) Damage categorization of glass/epoxy composite material under mode II delamination using Acoustic Emission Data: a clustering approach to elucidate Wavelet Transformation Analysis. Arab J Sci Eng 39:1325-1335. https://doi. org/10.1007/s13369-013-0712-0

38. Sharma S, Pathak AK, Singh VN et al (2018) Excellent mechanical properties of long length multiwalled carbon nanotube bridged Kevlar fabric. Carbon 137:104-117. https://doi.org/10.1016/j.carbon.2018.05. 017

39. Mourad AHI, Cherupurakal N, Hafeez F et al (2020) Impact strengthening of laminated kevlar/epoxy composites by nanoparticle reinforcement. Polymers 12:1-16. https://doi.org/10.3390/polym12122814

40. Dong C, Davies IJ (2015) Flexural strength of bidirectional hybrid epoxy composites reinforced by e glass and T700S carbon fibres. Compos B Eng 72:65-71. https://doi.org/10.1016/j.compositesb.2014. 11.031

41. Mourad AHI, Idrisi AH, Zaaroura N et al (2020) Damage assessment of nanofiller-reinforced woven kevlar KM2plus/Epoxy resin laminated composites. Polym Testing 86:106501. https://doi.org/10. 1016/j.polymertesting.2020.106501

42. Mourad AHI, Zaaroura N (2018) Impact of nanofillers incorporation on laminated nanocomposites performance. J Mater Eng Perform 27:4453-4461. https://doi.org/10.1007/s11665-018-3523-3

43. Stanag 4090 Standard - Small Arms Ammunition ( 9 mm Parabellum) (1982) Military Agency for Standardization, NATO. http://gigconcept sinc.com/files/STANAG4090-cartridge_9x19.pdf

44. Naghizadeh Z, Faezipour M, Pol MH et al (2018) Improvement in impact resistance performance of glass/epoxy composite through carbon nanotubes and silica nanoparticles. Proceed Inst Mech Eng Part L: J Mater: Des Appl 232:785-799. https://doi.org/10.1177/ 1464420716649403 
45. Bulut M, Erkliğ A, Yeter E (2016) Hybridization effects on quasistatic penetration resistance in fiber reinforced hybrid composite laminates. Compos B Eng 98:9-22. https://doi.org/10.1016/j.compo sitesb.2016.05.025

46. Muhi RJ, Najim F, de Moura MFSF (2009) The effect of hybridization on the GFRP behavior under high velocity impact. Compos B Eng 40:798-803. https://doi.org/10.1016/j.compositesb.2009.08.002

47. Srivastava AK, Gupta V, Yerramalli CS, Singh A (2019) Flexural strength enhancement in carbon-fiber epoxy composites through graphene nano-platelets coating on fibers. Compos B Eng 179:107539. https://doi.org/10.1016/j.compositesb.2019.107539
48. Liu F, Deng S, Zhang J (2017) Mechanical properties of epoxy and its carbon fiber composites modified by nanoparticles. J Nanomater 2017:14-16. https://doi.org/10.1155/2017/8146248

Publisher's Note Springer Nature remains neutral with regard to jurisdictional claims in published maps and institutional affiliations. 